Tropical Journal of Pharmaceutical Research November 2014; 13 (11): 1825-1831

ISSN: $1596-5996$ (print); 1596-9827 (electronic)

(C) Pharmacotherapy Group, Faculty of Pharmacy, University of Benin, Benin City, 300001 Nigeria.

All rights reserved.

Available online at http://www.tjpr.org

Original Research Article

http://dx.doi.org/10.4314/tjpr.v13i11.8

\title{
Inhibitory Effects of (-)-Epigallocatechin-3-gallate on Melanogenesis in Ultraviolet A-Induced B16 Murine Melanoma Cell
}

\author{
Yue-Rong Liang', Suyoung Kang ${ }^{1}$, Li Deng ${ }^{1}$, Li-Ping Xiang ${ }^{2}$ and Xin-Qiang \\ Zheng ${ }^{1 *}$ \\ ${ }^{1}$ Zhejiang University Tea Research Institute, Hangzhou 310058, ${ }^{2}$ Guizhou Tea and Tea Products Quality Supervision and \\ Inspection Center, Zunyi 563100, China \\ *For correspondence: Email: yrliang@zju.edu.cn; Tel/Fax: +86 57188982704
}

Revised accepted: 23 October 2014

\begin{abstract}
Purpose: To investigate the anti-melanogenesis effect of green tea compound, (-)-epigallocatechin-3gallate (EGCG), on B16 murine melanoma cell irradiated by ultraviolet $A$ (UVA) in the search for natural skin-lightening alternative agents.

Methods: B16 murine melanoma cells by UVA $\left(9.0 \mathrm{~J} / \mathrm{cm}^{2}\right)$ for 0 to $32 \mathrm{~min}$ and then incubated in Dulbecco's Modified Eagle's Medium (DMEM) with EGCG $(0-200 \mu \mathrm{g} / \mathrm{mL})$ for 2 days. Cell viability was determined by MTT method and cell protein was quantified using a PA102 Bradford protein assay kit. Activity of tyrosinase (TRY) was determined based on the oxidation rate of 3,4-dihydroxy phenylalanine (DOPA). The ultra-structure of the melanosomes was observed by transmission electron microscopy (TEM).

Results: TRY activity and melanin concentration were increased to $146.70 \pm 10.28 \%(p<0.05)$ and $157.06 \pm 6.37 \%(p<0.05)$, respectively, by $9.0 \mathrm{~J} / \mathrm{cm} 2$ UVA irradiation for $8 \mathrm{~min}$, compared to blank control without UV A and EGCG. EGCG inhibited the UV A induced increase in TRY activity and melanin level, and the optimum concentration of EGCG was $25 \mu \mathrm{g} / \mathrm{mL}$. TRY activity and melanin concentration were decreased to $64.71 \pm 4.41(p<0.05)$ and $86.24 \pm 5.15 \%(p<0.05)$, respectively, compared to blank (control) which was neither treated by UVA nor by EGCG. TEM showed that UVA induced the formation of melanosomes while EGCG inhibited UVA-induced melanosome maturation. Conclusion: EGCG inhibits UVA-induced melanogenesis via suppression of TRY activity and melanosome maturation and is thus a potential alternative to melanogenesis inhibitor.
\end{abstract}

Keywords: Green tea, Catechins, Melanin, Melanosome, Tyrosinase, Cell proliferation

\begin{abstract}
Tropical Journal of Pharmaceutical Research is indexed by Science Citation Index (SciSearch), Scopus, International Pharmaceutical Abstract, Chemical Abstracts, Embase, Index Copernicus, EBSCO, African Index Medicus, JournalSeek, Journal Citation Reports/Science Edition, Directory of Open Access Journals (DOAJ), African Journal Online, Bioline International, Open-J-Gate and Pharmacy Abstracts
\end{abstract}

\section{INTRODUCTION}

The color of human skin depends on the skin pigment, melanin, which is produced by oxidation of the amino acid, tyrosine, followed by polymerization in melanocytes. The first rate limiting enzyme during the synthesis of melanin is tyrosinase (TYR) which hydroxylates tyrosine into 3,4-dihydroxy phenylalanine (DOPA). DOPA is then further oxidized to form dopaquinone, and then transformed into pheomelanin and eumelanin through two different metabolic pathways, respectively. In the presence of cysteine, the dopaquinone is transformed into yellow-reddish pheomelanin. Under the action of tyrosinase related protein-1 (TRP-1) and tyrosinase related protein-2 (TRP-2), the 
dopaquinone is transformed into black-brown eumelanin [1].

Biosynthesis and metabolism of melanin are controlled by several factors, among which ultraviolet radiation (UVR) is the most important one. UVR induces the accumulation of reactive oxygen species (ROS) which stimulates the secretion of hormones such as a-melanocytestimulating hormone ( $\alpha-\mathrm{MSH})$ and adrenocorticotropic hormone (ACTH), endothelin-1(ET-1), as well as basic fibroblast growth factor (bFGF), stem cell factor (SCF) and immune factors $[2,3]$. These induced factors stimulate the expression of microphthalmiaassociated transcription factor (MITF) by acting melanocortin receptor 1 (MC1R), endothelin receptor (EDNR) and stem cell growth factor receptor (SCFR) on the melanin cell membrane through the pathway of cyclic adenosine monophosphate protein kinase A (cAMP-PKA) or nitric oxide/cyclic guanylate monophosphate protein kinase G (NO/cGMP-PKG). MITF regulates the activities of TYR, TRP-1 and TRP2 , leading to changes in melanogenesis [4-6]. Some melanogenesis inhibitors such as hydroqinone are banned in cosmetics owing to their side effects [7]. With the increasing attention to improve skin color, many cosmetic and pharmaceutical companies are focusing on search for alternative skin-lightening agents [7].

Green tea (-)-epigallocatechin gallate (EGCG) is reported to have many physiological activities including anti-UVR induced damages [8,9]. EGCG protects human skin fibroblasts from photo-damage induced by UVA [8] and reduces melanin synthesis via reduction of the protein levels of MITF $[9,10]$. The present study set to investigate the effect of EGCG on TRY activity and melanogenesis in UV $A$ induced B16 murine melanoma cell lines.

\section{EXPERIMENTAL}

\section{Materials}

The B16 murine melanoma cell line (B16 cells) was purchased from Shanghai Cell Bank of Chinese Academy of Science (Shanghai, China). EGCG was supplied by CinoTea Co, Ltd (Hangzhou, China). Dulbecco's Modified Eagle's medium (DMEM), fetal bovine serum (FBS), Trizol reagent were Gibco products (Life Technologies, Grand Island, USA). Streptomycin, penicillin and 3,4-dihydroxy phenylalanine (DOPA) were purchased from the Sangon Biological Engineering Technology Co., Ltd,
(Shanghai, China). PA102 Bradford protein assay kit was purchased from TianGen Biotech (Beijing) Co., Ltd., (Beijing, China). DNA Generuler and RT- PCR kit were purchased from Thermo Fisher Scientific (China) Co., Ltd (Beijing, China). The cDNA synthesis kit and SYBR Premix Ex Taq were purchased from Takara Biotechnology (Dalian) Co., Ltd., (Dalian, China). Methylthiazolyl diphenyl-tetrazolium bromide (MTT), trypsase (TRY), TritonX-100 and phenylmethyl sulfonylfluoride (PMSF) were Amresco products (Amresco LLC, Solon, USA). The other reagents used in the present study were AR grade chemicals (Sinopharm Chemical reagent Co., Ltd., Beijing, China).

\section{Cell culture}

The B16 cells were grown in $25 \mathrm{~cm}^{2}$ dishes containing DMEM medium at $37{ }^{\circ} \mathrm{C}$ and $5 \%$ $\mathrm{CO}_{2}$, with relative humidity $>90 \%$. Treatment was started when the cells were grown to confluence $>80 \%$.

\section{UVA irradiation}

The B16 cells were seeded into six-well plates containing DMEM medium, with $8 \times 10^{4}$ cells each well, allowed to grow until $80-90 \%$ confluence, drained the solution medium and then washed two times using phosphate buffered saline (PBS). The cells were irradiated under UVA lamps at $9.0 \mathrm{~J} / \mathrm{cm}^{2}$ for $0,4,8,16$ and $32 \mathrm{~min}$. The PBS was drained and the cells were cultured in $3 \mathrm{~mL}$ DMEM medium for further 2 days. Indicators of cell viability, melanim concentration, TRY activity and protein content were determined as described in the following sections. All the tests were carried out in triplicates.

\section{Cell viability assay}

The cell viability was determined by MTT assay method. The MTT was dissolved in PBS at a concentration of $5 \mathrm{mg} / \mathrm{mL}$. The cells to be tested were seeded onto a 96-well plate at a density of $1 \times 10^{5}$ cells per well and cultured for 4 h. $400 \mu \mathrm{L}$ of the MTT solution was added to each culture well, and then the cells in the plates were incubated at $37{ }^{\circ} \mathrm{C}$ in an atmosphere of $5 \% \mathrm{CO}_{2}$ for further $4 \mathrm{~h}$, poured out the solution medium, added $200 \mu \mathrm{L}$ dimethyl sulfoxide (DMSO) to each well, pipetted up and down to dissolve the crystals inside. Absorbance of the samples was measured at $492 \mathrm{~nm}$ using an ELISA reader (ThermoFisher, Massachusetts, USA). The results of cell viability were presented as the 492 $\mathrm{nm}$ absorbance ratio of the tested samples to the control test. 


\section{Determination of protein}

Protein content was determined using a PA102 Bradford protein assay kit (TianGen Biotech (Beijing) Co., Ltd., Beijing, China) according to the manufacturer's instructions. The treated cells were washed in iced PBS for 2 times, lysed with $400 \mu \mathrm{L}$ of $1 \%$ Triton-X-100 containing $0.1 \mathrm{mM}$ PMSF and $1.0 \mathrm{mM} \mathrm{NaF}$, frozen at $-80^{\circ} \mathrm{C}$ for 30 $\mathrm{min}$, resolved at room temperature, and finally centrifuged at $12000 \mathrm{r} / \mathrm{min}$ for $10 \mathrm{~min}$. $20 \mu \mathrm{L}$ of the supernatant was diluted with $180 \mu \mathrm{L}$ of $0.1 \mathrm{M}$ phosphate buffer ( $\mathrm{pH}$ 7.0). The protein content of the sample was determined according to the instructions of the Bradford protein assay kit.

\section{EGCG treatment}

The B16 cells were seeded into six-well plates containing DMEM solution medium, with $8 \times 10^{4}$ cells each well, allowed to grow until $80-90 \%$ confluence, poured into the DMEM and the cells washed two times in PBS. The cells were cultured again in DMEM media containing 0,25 , $50,75,100$ and $150 \mu \mathrm{g} / \mathrm{mL}$ EGCG respectively for 2 days. The test was carried out in triplicates.

\section{Treatment of UVA and EGCG}

The B16 cells were cultured and irradiated by UVA at $9.0 \mathrm{~J} / \mathrm{cm}^{2}$ for $8 \mathrm{~min}$ and then cultured in DMEM containing $0,12.5,25,50,100$ and 200 $\mu \mathrm{g} / \mathrm{mL}$ EGCG for 2 days. Ultra-structure of melanosomes was observed by transmittance electron microscopy (TEM). The test was carried out in triplicates.

\section{Biochemical assays}

Melanin content was determined by method described by Ohgidani et al [11]. The treated cells were washed using PBS for 2 times and completely lysed by $1 \mathrm{~N} \mathrm{NaOH}$ containing $10 \%$ DMSO. The amount of melanin in the lysate was measured spectrophotometrically at $405 \mathrm{~nm}$ [11]. To eliminate the errors due to the difference in cell number between treatments, the results were expressed as melanin content per $\mathrm{g}$ of cell protein.

TRY activity was determined based on the oxidation rate of L-DOPA as described by Jian et al [12]. The above treated cells were washed twice with PBS and then lysed with $400 \mu \mathrm{L}$ of 1 $\%$ Triton-X-100 containing $0.1 \mathrm{mM}$ PMSF and 1.0 $\mathrm{mM} \mathrm{NaF}$. The lysates were frozen at $-80{ }^{\circ} \mathrm{C}$ for $30 \mathrm{~min}$. The frozen lysates were then resolved at room temperature and centrifuged at $12000 \mathrm{r} / \mathrm{min}$ for $10 \mathrm{~min} .110 \mu \mathrm{L}$ of the supernatant was mixed with $110 \mu \mathrm{L} 0.1 \%$ L-DOPA, which was dissolved in $0.1 \mathrm{M}$ phosphate buffer $(\mathrm{pH} 7.0)$ in each well of the 6-well plates, incubated at $37^{\circ} \mathrm{C}$ for $30 \mathrm{~min}$. Absorbance was measured at $490 \mathrm{~nm}$ in a spectrophotometer. The results were expressed as melanin content per $\mathrm{g}$ of cell protein.

\section{Transmission electron microscopy (TEM)}

The B16 cells were fixed with $0.25 \%$ glutaraldehyde overnight and then rinsed with PBS for 3 times. The cells were set in $4 \%$ agar noble and post-fixed in $1 \%$ osmium tetroxide for $120 \mathrm{~min}$. The fixed cells were dehydrated in concentration gradient of ethanol solutions (50 $\%, 70 \%, 80 \%, 90 \%, 95 \%$, and $100 \%$ ). During the dehydration, the samples were left to stand for $15 \mathrm{~min}$ at each ethanol concentration level. The dehydrated cells samples were embedded in Epon 812. Ultra-thin sections of the embedded cell samples were prepared as described by $\mathrm{Xu}$ et al [13], and double-stained with uranyl acetate and lead citrate, and then observed under a JEM-1230 electron microscope (JEOM Ltd, Tokyo, Japan).

\section{Data analysis}

The tests in the present study were carried out in triplicates. The data statistical analysis was performed using Turkey's range test on a statistic analysis system (SAS) version 9.1. The results are expressed as mean \pm standard deviation (SD).

\section{RESULTS}

\section{Effect of UVA on viability and melanogenesis of B16 cells}

Table 1 shows that the proliferation of the tested B16 cells was decreased with UV A irradiation time at $9.0 \mathrm{~J} / \mathrm{cm}^{2}$, but there was no significant difference $(p>0.05)$ between 4 min irradiation and control $(0 \mathrm{~min})$. As the UV A irradiation time was extended to $8 \mathrm{~min}$, the cell proliferation viability decreased to $94.33 \pm 0.68 \%$ of that of control group $(p<0.05)$. When the irradiation time was further extended, the cell proliferation viability was sharply decreased. The melanin concentration increased with extension of UV A irradiation time up to $32 \mathrm{~min}$, with sharp increase between 8 and 16 min. TRY activity increased up to $16 \mathrm{~min}$ of UV A irradiation, and decreased afterward. There was a sharp decline in TRY activity between 16 and 24 min irradiation. This might be caused by seriously damages of B16 cells induced by long term UV A irradiation, which could be seen in cell proliferation. These results show that short term UV A irradiation 
increased TRY activity and promoted the biosynthesis and accumulation of melanin in B16 cell, but long term UV A irradiation would seriously damage B16 cells, resulting in sharp decrease in TRY activity. Based on these results, 8 min irradiation time was used in the subsequent tests.

\section{Effects of EGCG on melanogenesis in UV A treated B16 cells}

Table 2 shows that EGCG had inhibitory effects on the B16 cell proliferation, TRY activity and melanin concentration in a dose-dependent manner. However, there were no significant differences in cell proliferation, TRY activity and melanin concentration between $25 \mu \mathrm{g} / \mathrm{mL}$ EGCG and control ( $0 \mu \mathrm{g} / \mathrm{mL}$ EGCG). These suggest that low dosage ( $25 \mu \mathrm{g} / \mathrm{mL}$ or below) of EGCG had not harmful effect on the B16 cells, but higher dosage of EGCG (> $50 \mu \mathrm{g} / \mathrm{mL}$ ) had poisonous effect on the B16 cells in dose dependent manner.

Compared to blank control neither treated by UV A nor by EGCG, UV A irradiation induced significant increases $(p<0.05)$ in melanin level and TRY activity as the UV A irradiated cell was not incubated with EGCG. However, when the
UV A irradiated cells were incubated with 12.5 $200 \mu \mathrm{g} / \mathrm{mL}$ of EGCG, the melanin level and TRY activity were significantly decreased $(p<0.05)$, suggesting that EGCG suppressed the UV $A$ induced increase in TRY activity and melanogenesis. Cell proliferation in the group without EGCG treatment was significantly lower than those incubated in media containing 12.5 $25.0 \mu \mathrm{g} / \mathrm{mL}$ EGCG $(p<0.05)$, but significantly higher than those incubated in media containing 50.0 - $100.0 \mu \mathrm{g} / \mathrm{mL}$ EGCG $(p<0.05)$ (Table 3), showing that high level EGCG suppressed viability of B16 cell.

\section{Effect of EGCG on melanosome maturation in UVA induced melanoma cells}

TEM revealed that mature melanosomes in the UV A irradiated B16 cells (Figure 1, B-1 and B-2) markedly increased, compared with the control cells which were not irradiated by UV A (Figure 1, A-1 and A-2). However, the mature melanosomes significantly decreased as the UV $A$ irradiated B16 cells were incubated in medium containing EGCG $(25 \mu \mathrm{g} / \mathrm{mL})$ (Figure 1, C-1 and $\mathrm{C}-2)$. These suggest that EGCG suppressed the UV A induced synthesis of melanosomes in the B16 cells.

Table 1: Effect of UVA on cell proliferation, melanin level and TRY activity of B16 cells (mean \pm SD) ${ }^{1}$

\begin{tabular}{lccc}
\hline $\begin{array}{l}\text { UVA irradiation } \\
\text { time }^{2}(\mathbf{m i n})\end{array}$ & $\begin{array}{c}\text { Cell proliferation } \\
\mathbf{( \% )}^{\mathbf{3}}\end{array}$ & $\begin{array}{c}\text { TRY activity } \\
\mathbf{( \% )}^{\mathbf{3}}\end{array}$ & $\begin{array}{c}\text { Melanin } \\
\mathbf{( \% )}^{\mathbf{3}}\end{array}$ \\
\hline 0 & $100.0 \pm 0.31^{\mathrm{a}}$ & $100.0 \pm 12.46^{\mathrm{c}}$ & $100.0 \pm 7.35^{\mathrm{e}}$ \\
4 & $99.27 \pm 0.96^{\mathrm{a}}$ & $122.7 \pm 3.14^{\mathrm{b}}$ & $145.4 \pm 7.21^{\mathrm{d}}$ \\
8 & $94.33 \pm 0.68^{\mathrm{b}}$ & $121.4 \pm 3.19^{\mathrm{b}}$ & $141.9 \pm 3.38^{\mathrm{a}}$ \\
16 & $75.75 \pm 0.40^{\mathrm{c}}$ & $184.5 \pm 5.65^{\mathrm{a}}$ & $557.7 \pm 13.46^{\mathrm{c}}$ \\
24 & $26.23 \pm 0.09^{\mathrm{a}}$ & $63.04 \pm 1.93^{\mathrm{c}}$ & $830.0 \pm 16.36^{\mathrm{b}}$ \\
32 & $15.88 \pm 0.06^{\mathrm{e}}$ & $60.70 \pm 4.39^{\mathrm{d}}$ & $1151.0 \pm 10.09^{\mathrm{a}}$ \\
\hline
\end{tabular}

${ }^{1} S D=$ standard deviation. Data marked with Data marked with different alphabetic letters are statistically significantly different at $p<0.05(n=3) ;{ }^{2}$ UV A intensity was $9.0 \mathrm{~J} / \mathrm{cm}^{2}$; ${ }^{3}$ unit of measurement was expressed as the ratio of the tested sample value to control (0 min UV A irradiation) as the control value was set as $100 \%$

Table 2: Effect of EGCG on cell proliferation, melanin level and TRY activity in B16 cell (mean \pm SD) ${ }^{1}$

\begin{tabular}{|c|c|c|c|}
\hline $\begin{array}{l}\text { EGCG } \\
(\mu \mathrm{g} / \mathrm{mL})\end{array}$ & $\begin{array}{c}\text { Cell proliferation } \\
(\%)^{2}\end{array}$ & $\begin{array}{c}\text { TRY activity } \\
(\%)^{2}\end{array}$ & $\begin{array}{c}\text { Melanin } \\
(\%)^{2} \\
\end{array}$ \\
\hline 0 & $100.0 \pm 3.86^{\mathrm{a}}$ & $100.0 \pm 7.41^{\mathrm{a}}$ & $100.0 \pm 0.69^{a}$ \\
\hline 25 & $93.73 \pm 2.82^{a}$ & $99.72 \pm 2.66^{a}$ & $101.49 \pm 2.44^{a}$ \\
\hline 50 & $83.26 \pm 3.76^{b}$ & $98.80 \pm 3.216^{\mathrm{a}}$ & $87.97 \pm 4.53^{b}$ \\
\hline 75 & $68.73 \pm 3.12^{c}$ & $86.39 \pm 3.33^{b}$ & $87.57 \pm 3.08^{b}$ \\
\hline 100 & $67.09 \pm 3.27^{c}$ & $74.93 \pm 6.66^{c}$ & $68.81 \pm 1.91^{\mathrm{c}}$ \\
\hline 150 & $69.29 \pm 3.32^{c}$ & $44.18 \pm 15.12^{c}$ & $57.96 \pm 5.78^{\mathrm{C}}$ \\
\hline
\end{tabular}

${ }^{1} S D=$ standard deviation; data marked with different alphabetic letter was statistically significant different at $p<0$. 05 ( $n=3) ;{ }^{2}$ unit of measurement was expressed as the ratio of the tested sample value to control $(0 \mu \mathrm{g} / \mathrm{mL}$ EGCG) as the control value was set as $100 \%$ 
Table 3: Effect of EGCG on cell proliferation, melanin level and TRY activity in UVA treated B16 cell mean \pm $\mathrm{SD})^{1}$

\begin{tabular}{lccc}
\hline $\begin{array}{l}\text { EGCG } \\
(\boldsymbol{\mu g} / \mathbf{m L})^{2}\end{array}$ & $\begin{array}{c}\text { Cell proliferation } \\
\mathbf{( \% )}^{\mathbf{3}}\end{array}$ & $\begin{array}{c}\text { TRY activity } \\
(\mathbf{\%})^{\mathbf{3}}\end{array}$ & $\begin{array}{c}\text { Melanin } \\
\mathbf{( \% )}^{\mathbf{3}}\end{array}$ \\
\hline Blank control & $100.0 \pm 0.41^{\mathrm{a}}$ & $100.0 \pm 0.09^{\mathrm{b}}$ & $100.0 \pm 0.47^{\mathrm{D}}$ \\
0 & $86.91 \pm 0.29^{\mathrm{C}}$ & $146.7 \pm 10.28^{\mathrm{a}}$ & $157.1 \pm 6.37^{\mathrm{a}}$ \\
12.5 & $94.00 \pm 0.50^{\mathrm{b}}$ & $72.36 \pm 1.18^{\mathrm{c}}$ & $75.44 \pm 1.37^{\mathrm{d}}$ \\
25.0 & $93.14 \pm 0.18^{\mathrm{b}}$ & $64.71 \pm 3.41^{\mathrm{c}}$ & $86.24 \pm 5.15^{\mathrm{c}}$ \\
50.0 & $80.28 \pm 0.32^{\mathrm{a}}$ & $73.99 \pm 2.74^{\mathrm{c}}$ & $60.16 \pm 5.65^{\mathrm{e}}$ \\
100.0 & $78.87 \pm 0.38^{\mathrm{e}}$ & $19.69 \pm 1.40^{\mathrm{a}}$ & $53.99 \pm 2.01^{\dagger}$ \\
200.0 & $45.19 \pm 0.12^{\dagger}$ & $8.37 \pm 1.42^{\mathrm{e}}$ & $54.20 \pm 3.80^{\dagger}$ \\
\hline
\end{tabular}

${ }^{1} \mathrm{SD}=$ standard deviation; data marked with different alphabetic letter was statistically significant different at $p<$ $0.05(n=3) ;{ }^{2}$ cells were irradiated by $9.0 \mathrm{~J} / \mathrm{cm}^{2}$ UVA for $8 \mathrm{~min}$ and then incubated in DMEM media containing; the designated EGCG except for blank (control) which was treated neither with UVA nor EGCG; ${ }^{3 .}$ unit of measurement was expressed as the ratio of the tested sample value to control (0 $\mathrm{g} / \mathrm{mL} E G C G)$ as the control value was set as $100 \%$

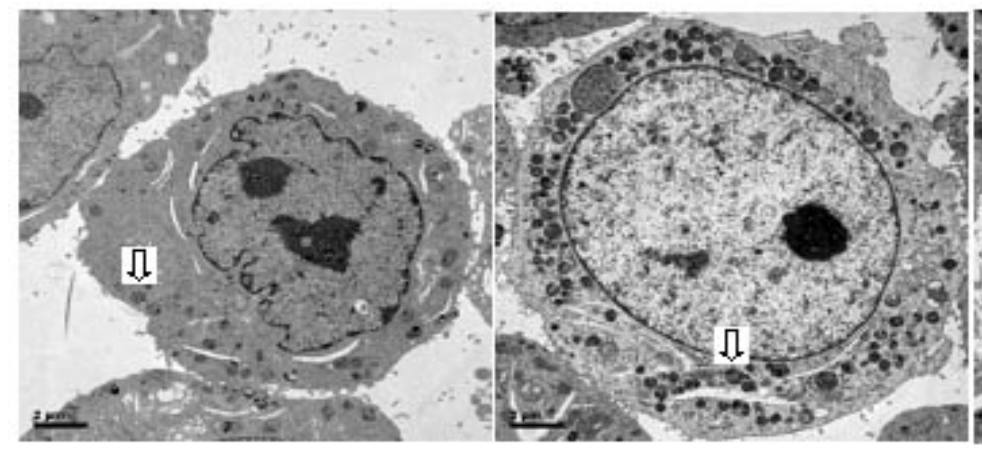

A-1

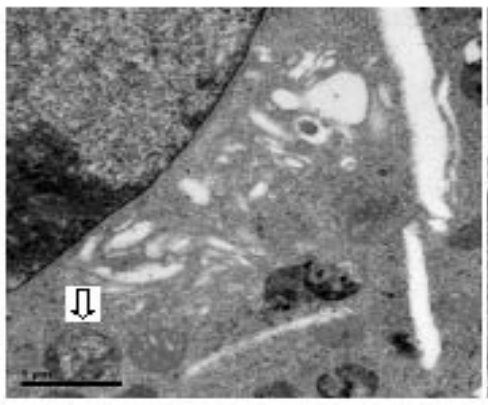

A-2
B-1

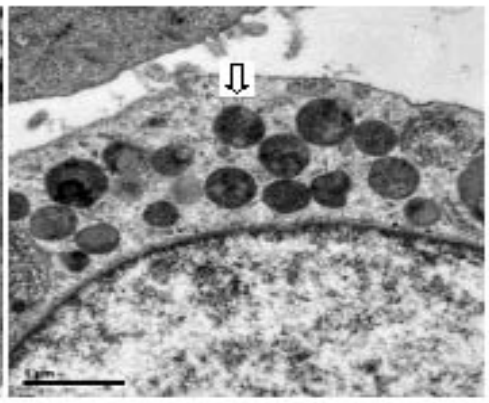

B-2

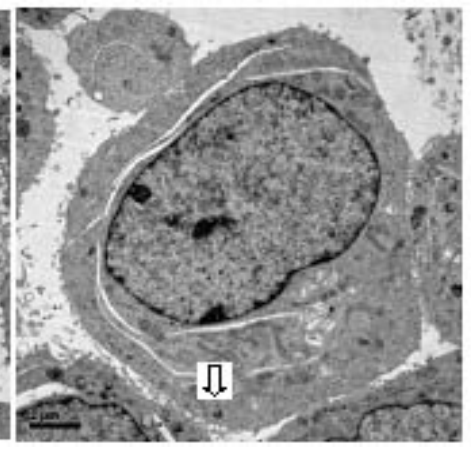

C-1

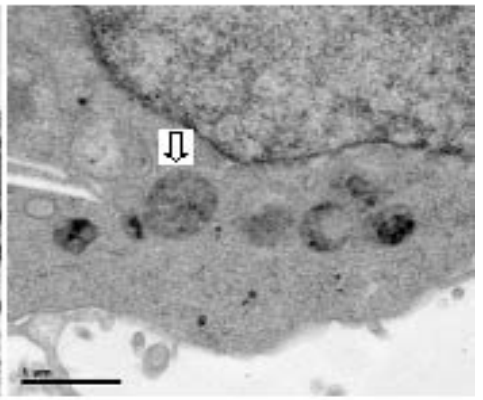

C-2

Figure 1: Effects of UVA and EGCG on melanosome maturation in B16 cells. $A=$ control (without UVA and EGCG); $B=$ radiated by $9.0 \mathrm{~J} / \mathrm{cm}^{2}$ UVA for $8 \mathrm{~min}$; $\mathrm{C}=$ irradiated by $9.0 \mathrm{~J} / \mathrm{cm}^{2}$ UVA for $8 \mathrm{~min}$ and then incubated in media containing $25 \mu \mathrm{g} / \mathrm{mL}$ EGCG for $2 \mathrm{~d}$. 1 = magnification $\times 8000 ; 2=$ magnification $\times 30000$. The arrow points to a melanosome

\section{DISCUSSION}

Our results show that low concentration of EGCG (12.5 - $25.0 \mu \mathrm{g} / \mathrm{mL}$ ) had no significant inhibitory effect on proliferation of B16 cells, but suppressed UV A irradiation induced melanogenesis and melanosome maturation. However, the melanogenesis inhibition mechanism of EGCG remains unknown. It was reported that extracts of Lycium chinense root inhibited melanogenesis in B16 F10 cells by down-regulation of both mitogen-activated protein kinases (MAPK) and protein kinase $A$
(PKA) signaling pathways or through its antioxidant properties [14]. Tyrosinase (TRY), a melanosomal membrane protein containing copper, is a key enzyme for melanin synthesis in melanocytes. Inulavosin, a melanogenesis inhibitor isolated from Inula nervosa, was reported to inhibit melanogenesis by enhancing a degradation of TRY in lysosomes [15]. The analyses of structure-activity relationship of inulavosin and its benzo-derivatives revealed that the hydroxyl and the methyl groups played a critical role in their inhibitory activity. Inulavosin and its benzo-derivatives showing inhibitory 
activity bind through hydrophobic interactions to the cavity of TRY below which the copperbinding sites were located. This cavity of TRY is required for the association with a chaperon that assisted in copper loading to TRY. Inulavosin might compete with the copper chaperon and inhibit the copper loading processing in living melanocytes [15]. Green tea EGCG is a benzoderivative with 8 hydroxyl groups, which has strong antioxidant activity $[8,16]$. It is deduced that the melanogenesis inhibitory effect of EGCG may be related to its abundant hydroxyl groups and its antioxidant activity. Human skin color stems from the epidermis, where melanocytes are localized, produce melanin. Skin-lightening products were developed for cosmetic purpose to obtain lighter skin complexion, and for clinical purpose to treat hyperpigmentary disorders such as melasma and solar lentigo. Identification and development of safe and natural skin-lightening bioactives have attracted much attention [7]. Hydroquinone was used as melanogenesis inhibitor to suppress skin pigmentation. However, the golden days of the hydroquinone seem to have come to an end as this potent skinlightening agent was confirmed to lead to permanent loss of melanocytes because of its oxidative damage of membrane lipids leading to irreversible loss of inherited skin color [17]. Because of its side effects, hydroquinone was banned by the European Committee [7]. Cosmetic and pharmaceutical researchers are focusing on researching for substituent skinlightening agents. This study shows that EGCG extracted from green tea will be a potential alternative. The melanogenesis inhibition mechanism underlying EGCG is considered to be related to its suppressing effects on TRY activity and melanosome maturation.

\section{CONCLUSION}

UVA induced melanogenesis in B16 cell by increasing TRY activity and mature melanosomes. Appropriate concentration (25 $\mu \mathrm{g} / \mathrm{mL}$ ) of green tea EGCG inhibited the UVA induced melanogenesis. The mechanism underlying EGCG inhibiting melanogenesis is considered to be its suppressing effects on TRY activity and melanosome maturation. The study shows that EGCG is a potential alternative of melanogenesis inhibitor and can be used in skinlightening products.

\section{ACKNOWLEDGEMENT}

This work was supported by National Key Technology R\&D Program in the 12th Five Year Plan of China (Project no. 2012BAD36B06-2).

\section{REFERENCES}

1. Ito S, Wakamatsu K. Chemistry of mixed melanogenesispivotal roles of dopaquinone. Photochem Photobiol 2008; 84: 582-592.

2. Sliney $\mathrm{DH}$. Estimating the solar ultraviolet radiation exposure to an intraocular eye implant. J Cataract Refract Surg 1987; 13: 296-301.

3. Giblin FJ, Leverenz VR, Padgaonkar VA, Unakar NJ, Dang L, Lin LR, Lou MF, Reddy VN, Borchman D, Dillon JP. UVA light in vivo reaches the nucleus of the guinea pig lens and produces deleterious, oxidative effects. Exp Eye Res 2002; 75: 445-458.

4. Yumaguchi Y, Hearing VJ. Physiological factors that regulate skin pigmentation. Biofactors 2009; 35:193199.

5. Maddodi $N$, Jayanthy A, Setaluri V. Shining light on skin pigmentation: the darker and the brighter side of effects of UV radiation. Photochem Photobiol 2012; 88: 1075-1082.

6. Liu JJ, Fisher DE. Lighting a path to pigmentation: mechanisms of MITF induction by UV. Pigment Cell Melanoma Res 2010; 23: 741-745.

7. Gillbro JM, Olsson MJ. The melanogenesis and mechanisms of skin-lightening agent-existing and new approaches. Int J Cosmet Sci 2011; 33: 210221.

8. Shin S, Wang $L X$, Zheng $X Q$, Xiang LP, Liang YR. Protective Effect of (-)-Epigallocatechin gallate against photo-damage induced by ultraviolet a in human skin fibroblasts. Trop J Pharm Res 2014; 13: 1079-1084.

9. Kim DS, Park SH, Kwon SB, Li K, Youn SW, Park KC. ()-Epigallocatechin-3-gallate and hinokitiol reduce melanin synthesis via decreased MITF production. Arch Pharm Res 2004; 27: 334-339.

10. Sato K, Toriyama M. Depigmenting effect of catechins. Molecules 2009; 14: 4425-4432.

11. Ohgidani $M$, Komizu $Y$, Goto $K$, Ueoka $R$. Antimelanogenic and antioxidative effects of residual powders from Shochu distillation remnants. Food Chem 2012; 132: 2140-2143.

12. Jian $D$, Jiang $D$, Su J, Chen $W, H u X L, K u a n g Y H$, Xie $H F$, Li J, Chen $X$. Diethylstilbestrol enhances melanogenesis via cAMP-PKA-mediating upregulation of tyrosinase and MITF in mouse $B 16$ melanoma cells. Steroids 2011; 76: 1297-1304.

13. $X u J Y, W u L Y$, Zheng $X Q$, Lu JL, Wu MY, Liang, YR. Green tea polyphenols attenuating ultraviolet $B$ induced damage to human retinal pigment epithelial cells in vitro. Invest Ophth Vis Sci 2010; 51: 66656670.

14. Huang HC, Huang WY, Tsai TC, Hsieh WY, Ko WP, Chang KJ, Chang TM. Supercritical fluid extract of Lycium chinense Miller root inhibition of melanin production and its potential mechanisms of action. BMC Complement Altern Med 2014; 14: 208-217. 
15. Fujita $H$, Menezes JCJMDS, Santos SM, Yokota S, Kamat SP, Cavaleiro JAS, Motokawa T, Kato T, Mochizuki M, Fujiwara T. Inulavosin and its benzoderivatives, melanogenesis inhibitors, target the copper loading mechanism to the active site of tyrosinase. Pigment Cell Melanoma Res 2014; 27:376-386.
16. Li NN, Deng L, Xiang LP, Liang YR. Photoprotective effect of tea and its extracts against ultraviolet radiation-induced skin disorders. Trop J Pharm Res 2014; 13: 475-483.

17. Briganti S, Camera E, Picardo M. Chemical and instrumental approaches to treat hyperpigmentation. Pigment Cell Res 2003, 16: 101-110. 